\title{
Unusual Catalytic Process Involving OH and NH Exchange
}

\author{
Ramadan M. Ramadan*, Ahmad K. Abu Al-Nasr \\ Applied Chemistry Department, Faculty of Applied Science, Taibah University, \\ Almadinah Almunawrah, KSA \\ Email: ${ }^{*}$ __m_ramadan@yahoo.com
}

Received November 22, 2011; revised February 2, 2012; accepted February 21, 2012

\begin{abstract}
Interaction of some transition metals species with a Schiff base, 1, derived from 4,6-diacetylresorcinol and 2-amino5-methylphenol (1:2 mole ratio) yielded the two compounds 4-ethanimidoyl-6-[(1E)-N-(2-hydroxy-4-methylphenyl) ethanimidoyl]benzene-1,3-diol, 2, and 4,6-diacetyl-1,3-diaminobenzene, 4 via unusual catalytic process involving $\mathrm{OH}$ and $\mathrm{NH}$ exchange. All the compounds are characterized by elemental analysis, IR, mass and ${ }^{1} \mathrm{H}$ NMR. The structure of the two compounds $\mathbf{2}$ and $\mathbf{4}$ are also determined by X-ray analysis. The crystal structure analysis revealed that the two compounds crystallized in the monoclinic space group $P 2_{1} / \mathrm{c}$ with a $\mathrm{Z}$ value of 4 .
\end{abstract}

Keywords: Bicompartment Ligand; Schiff Bases; Diaminobenzene; X-Ray Analysis

\section{Introduction}

Coordination chemistry of macrocyclic ligands has shown to be interesting subject of current research in the last two decades $[1,2]$. Importance in designing new macrocyclic ligands arises mainly from their use as models for protein-metal binding sites in a substantial array of metalloproteins in biological systems, such as the synthetic ionophores, models for the magnetic exchange phenomena, therapeutic reagents in chelate therapy for treatment of metal intoxication and the cyclic antibiotics that retain their antibiotic actions to specific metal complexation [3-6]. On the other hand, the synthesis of binuclear complexes in which a ligand structure accommodates two metal centers in close proximity but in a different compartments separated by an intervening group represents important criteria in the study of transitionmetal systems. In such molecularly designed ligands, the aromatic rings are expected to act as a bridge and a rigid separator between the two compartments. The interest in these complexes corresponds to their ability to serve as simple models for multi-metal-centered catalysts $[7,8]$. From these types of ligands, the macrocyclic Schiff bases exhibited great importance in macrocyclic chemistry because they can selectively chelate certain metal ions depending on the number, type and position of their donor atoms, the ionic radii of the metal centers, and the coordinating property of the counter ions [9]. In this report, we synthesized a molecularly designed macrocyclic Schiff base to serve as a host for two metal centers. However, unusual behavior was observed in the attempts

"Corresponding author. of interactions of this ligand with different transition metal species.

\section{Experimental}

\subsection{Reagents}

4,6-diacetylresorcinol, 2-amino-5-methylphenol, ferric chloride, nickel nitrate and palladium(II) chloride were purchased from Aldrich. All the solvents were of analytical reagent grade and were purified by standard methods.

\subsection{Instruments}

IR measurements ( $\mathrm{KBr}$ discs) were carried out on a Unicam-Mattson 1000 FT-IR spectrometer. NMR measurements were performed on a Spectrospin-Bruker 300 $\mathrm{MHz}$ spectrometer. Samples were dissolved in $\left(\mathrm{CD}_{3}\right)_{2} \mathrm{SO}$ and TMS was used as an internal reference. Elemental analyses were performed on Perkin-Elmer $2400 \mathrm{CHN}$ elemental analyzer. Mass spectrometry measurements of the solid complexes $(70 \mathrm{eV}, \mathrm{EI})$ were carried out on a Finnigan MAT SSQ 7000 spectrometer.

\subsection{Preparation of 4,6-Di[(1E)-N-(2-hydroxy-4- methylphenyl)ethanimidoyl]-benzene-1, 3-diol (1)}

Solutions of 4,6-diacetylresorcinol and 2-amino-5methylphenol in absolute ethanol with molar ratio 1:2 were mixed together and heated to reflux for $1 \mathrm{~h}$. The reaction mixture was then cooled and the formed yellow precipitate was isolated by filtration. The crude was recrystallized from hot ethanol to give yellow fine crystals. 
The compound was left to dry under vacuum for several hours (yield $86 \%$ ). M.p. $268^{\circ} \mathrm{C}-270^{\circ} \mathrm{C}$; M. Wt $=404.47$, $m / z=388(\mathrm{P}-\mathrm{OH})^{+}$; Elemental analysis, Found (Calc.): C, 71.20 (71.27), H, 6.03 (5.98), N, 6.88 (6.92); IR: 3379 (m, OH), $3310(\mathrm{~m}, \mathrm{OH}), 1615(\mathrm{sh}, \mathrm{C}=\mathrm{N}), 1593(\mathrm{vs}, \mathrm{C}=\mathrm{N})$, 1530 (vs, C=C), 1460 (s, C=C), 1433 (s, C=C), 864 - 570 (m, Ph); ${ }^{1} \mathrm{H}$ NMR: 12.70 (s, $\left.2 \mathrm{H}, \mathrm{OH}\right), 9.46$ (s, $\left.2 \mathrm{H}, \mathrm{OH}\right)$, $8.41,8.25$ (d, $2 \mathrm{H}, \mathrm{Ph}), 6.88$ - 6.1 (m, $6 \mathrm{H}, \mathrm{Ph})$, [2.40 (s), $\left.2.38(\mathrm{~s}), 2.26(\mathrm{~s}), 2.08(\mathrm{~s}), 12 \mathrm{H}, \mathrm{CH}_{3}\right]$.

\subsection{Preparation of 4-Ethanimidoyl-6-[(1E)- $\mathrm{N}$-(2-hydroxy-4-methylphenyl)ethanimidoyl] -benzene-1,3-diol (2)}

A mixture of compound 1 and $\mathrm{FeCl}_{3}$ (1:1 mole ratio) in absolute ethanol was heated to reflux for $5 \mathrm{~min}$ and then left to stand at room temperature for few hours. The formed yellow residue was separated by filtration. The compound was recrystallized from hot ethanol to give yellow crystals. The crystals were left to dry under vacuum for several hours (yield $42 \%$ ). M.p. $230^{\circ} \mathrm{C}-232^{\circ} \mathrm{C}$; M. Wt $=298.34, m / z=299 \mathrm{P}^{+}$; Elemental analysis, Found (Calc.): C, 68.38 (68.44), H, 6.12 (6.08), N, 9.30 (9.39); IR: 3431 (b, OH), 3069 (m, NH), $1636(\mathrm{~s}, \mathrm{C}=\mathrm{N})$, $1611(\mathrm{~s}, \mathrm{C}=\mathrm{N}), 1592(\mathrm{~s}, \mathrm{C}=\mathrm{N}), 1536(\mathrm{~s}, \mathrm{C}=\mathrm{C}), 1463$ (m, $\mathrm{C}=\mathrm{C}), 1435(\mathrm{~m}, \mathrm{C}=\mathrm{C}), 876-783(\mathrm{~m}, \mathrm{Ph}) ;{ }^{1} \mathrm{H}$ NMR: $17.21(\mathrm{~s}, 1 \mathrm{H}, \mathrm{C}=\mathrm{NH}), 12.72(\mathrm{~s}, 1 \mathrm{H}, \mathrm{OH}), 9.71(\mathrm{~d}, 2 \mathrm{H}$, $\mathrm{OH}), 8.26$ (d, $2 \mathrm{H}, \mathrm{Ph}), 6.89-6.20$ (m, $3 \mathrm{H}, \mathrm{Ph}),[2.65$ (s), 2.64 (s), 2.50 (s), 2.49 (s), 2.39 (s), 2.25 (s) $9 \mathrm{H}, \mathrm{CH}_{3}$ ].

\subsection{Preparation of 4,6-Diacetyl-1,3- diaminobenzene (4)}

Similar procedure was employed as that used for preparation of compound 2 but the mixture was heated to reflux for $3 \mathrm{~h}$. The color of the solution was turned to dark brown. The mixture was left to stand overnight at room temperature where white needle crystals were isolated. The crystals were washed several times by warm absolute ethanol and then left to dry under vacuum (yield $53 \%$ ). M.p. $186^{\circ} \mathrm{C}-188^{\circ} \mathrm{C} ; \mathrm{M} . \mathrm{Wt}=192.22, \mathrm{~m} / \mathrm{z}=194$ $(\mathrm{P}+1)^{+}$; Elemental analysis, Found (Calc.): C, 62.45 (62.49), H, 6.32 (6.29), N, 14.52 (14.57); IR: 3215 (m, $\mathrm{NH}), 3076$ (m, NH), 1655 (s, CO), 1587 (s, CO), 1486 (m, C=C), $1427(\mathrm{~m}, \mathrm{C}=\mathrm{C})$; ${ }^{1} \mathrm{H}$ NMR: 12.72 (bs, $2 \mathrm{H}$, O..H..N), 8.41, 8.25 (s, $2 \mathrm{H}, \mathrm{Ph}), 6.41$ (bs, $2 \mathrm{H}, \mathrm{NH})$, [2.68 (s), $\left.2.65(\mathrm{~s}), 2.63(\mathrm{~s}), 2.51(\mathrm{~s}), 6 \mathrm{H}, \mathrm{CH}_{3}\right]$.

\subsection{X-Ray Structure Determination}

All X-ray measurements were made at room temperature using suitable crystals for data collection. Accurate lattice parameters were determined from least squares refinements of well-centered reflections in the ranges 2.91 $\leq \theta \leq 27.49$ for compound 2 and $2.91 \leq \theta \leq 26.02$ for compound 4. During data collection, three standard reflections were periodically observed and showed no significant intensity variations. The ranges of $h, k$ and $l$ are 0 $\leq h \leq 14 ; 0 \leq k \leq 12$ and $-17 \leq l \leq 16$ for compound 2 , and $0 \leq h \leq 8 ; 0 \leq k \leq 14$ and $-14 \leq l \leq 13$ for compound 4. 5456 (2) and 2725 (4) unique reflections were measured of which 2018 (2) and 1021 (4) had $I>3: 00 \sigma(I)$. These observed reflections were used for structure determination and refinements. The crystallographic data are presented in Table 1. All Diagrams and calculations were performed using maXus crystallographic software package (Nonius, Delft \& MacScience, Japan). The structures were determined by direct methods SIR 92 [10] and refined by full matrix least-squares methods maXus [11]. The displacement factors of non-hydrogen atoms of the two compounds were refined with anisotropic thermal parameters. The hydrogen atoms were refined isotropically. The function minimized was

$\left[\sum \mathrm{W}\left(\left|\mathrm{F}_{\mathrm{O}}\right|-\left|\mathrm{F}_{\mathrm{c}}\right|^{2}\right) / \sum \mathrm{W}\left|\mathrm{F}_{\mathrm{o}}\right|^{2}\right]^{1 / 2}$ with $\mathrm{w}=1 / \delta^{2}\left(\mathrm{~F}_{\mathrm{o}}\right)^{2}+$ $0.0300\left(\mathrm{~F}_{\mathrm{o}}\right)^{2}$. The final $\mathrm{R}$ and $\mathrm{R}_{\mathrm{w}}$ values are given in Table 1 .

Table 1. The crystal parameters for compounds 2 and 4.

\begin{tabular}{|c|c|c|}
\hline Crystal parameters & 2 & 4 \\
\hline Empirical formula & $\mathrm{C}_{17} \mathrm{H}_{18} \mathrm{~N}_{2} \mathrm{O}_{3}$ & $\mathrm{C}_{10} \mathrm{H}_{12} \mathrm{~N}_{2} \mathrm{O}_{2}$ \\
\hline Fw & 298.34 & 192.22 \\
\hline Crystal system & Monoclinic & Monoclinic \\
\hline Space group & $P 2_{1} / c$ & $P 2_{1} / c$ \\
\hline$a / \AA$ & $11.4842(3)$ & $7.1033(4)$ \\
\hline$b / \AA$ & $9.7771(3)$ & $11.3804(6)$ \\
\hline$c / \AA$ & $13.1498(4)$ & $11.6764(7)$ \\
\hline$\alpha / \operatorname{deg}$ & $90.00^{\circ}$ & $90.00^{\circ}$ \\
\hline$\beta /$ deg & $99.988(2)^{\circ}$ & $100.493(3)^{\circ}$ \\
\hline$\gamma / \operatorname{deg}$ & $90.00^{\circ}$ & $90.00^{\circ}$ \\
\hline$V / \AA$ & $1454.11(7)$ & $928.12(9)$ \\
\hline$Z$ & 4 & 4 \\
\hline$T / \mathrm{K}$ & 298 & 298 \\
\hline$\rho_{\text {calc }} / \mathrm{g} \cdot \mathrm{cm}^{-3}$ & 1.363 & 1.376 \\
\hline$\mu / \mathrm{cm}^{-1}$ & 0.09 & 0.10 \\
\hline$R^{\mathrm{a}}$ & 0.087 & 0.096 \\
\hline$R_{\mathrm{w}}^{\mathrm{b}}$ & 0.178 & 0.188 \\
\hline$(\mathrm{Mo} K \alpha) / \AA$ & 0.71073 & 0.71073 \\
\hline
\end{tabular}




\section{Results and Discussion}

\section{IR and NMR Studies}

The Schiff base 4,6-di[(1E)-N-(2-hydroxy-4-methyl-phenyl)-ethanimidoyl]benzene-1,3-diol, 1, was prepared by the condensation reaction of 4,6-diacetylresorcinol and 2-amino-5-methylphenol in 1 to 2 molar ratio (Scheme 1). This Schiff base was molecularly designed to be used as a bicompartment ligand. The IR spectrum of $\mathbf{1}$ showed characteristic stretching frequencies due to the functional groups [12]. Also, the presence of the $\mathrm{OH}$ groups was confirmed by ${ }^{1} \mathrm{H}$ NMR. Direct interaction of compound $\mathbf{1}$ with some transition metals species such as Fe(III), Ni(II) and $\mathrm{Pd}(\mathrm{II})$ in ethanol exhibited unusual catalytic behavior to give the two compounds 4-ethani-midoyl-6-[(1E)N-(2-hydroxy-4-methylphenyl) ethanimidoyl] benzene-1, 3diol, 2, and 4,6-diacetyl-1,3-diaminobenzene, 4. Interestingly, this catalytic process was deactivated by carrying out the reactions in basic medium, i.e., by addition of sodium hydroxide. The two compounds 2, 4 were characterized by elemental analysis, IR, ${ }^{1} \mathrm{H}$ NMR as well as X-ray crystal structure. The IR spectra of both $\mathbf{2}$ and $\mathbf{4}$ showed characteristic bands corresponding to the functional groups in the compounds [12]. Interestingly, the ${ }^{1} \mathrm{H}$ NMR spectrum of compound $\mathbf{4}$ showed broad signals at 12.72 and $6.41 \mathrm{ppm}$ due to both $\mathrm{OH}$ and $\mathrm{NH}$. Therefore, the structure of the compound in solution is different from the solid state structure which indicated by X-ray analysis. The presence of a signal at $12.72 \mathrm{ppm}$ could be due to hydrogen bonding between one of the $\mathrm{NH}_{2}$ protons and the carbonyl oxygen [13-16].

A plausible mechanism for the formation of the two compounds 2 and 4 is given in Scheme 2. It is suggested that the interaction of the metal ions with the bicompartment Schiff base, 1, caused fragmentation of the base to give compound 2 (Scheme 1). On the other hand, further reaction with the metal ions with 2 might lead to the formation of intermediate 3 , also, via fragmentation of 2 . The existence of this intermediate was suggested according to ${ }^{1} \mathrm{H}$ NMR evidence. Also, the presence of both $\mathrm{NH}$ and $\mathrm{OH}$ signals in the ${ }^{1} \mathrm{H}$ NMR spectrum of compound 4 is additional evidence. However, attempts to isolate intermediate 3 in the solid state were unsuccessful. Scheme 2 shows a speculated mechanism for the formation of 4,6-diacetyl-1,3-diaminobenzene, 4, through a radical mechanism. To our knowledge, this is the first example observed for such type of exchange on a phenyl ring. However, the proton $\mathrm{NH} / \mathrm{OH}$ exchange using ${ }^{1} \mathrm{H}$, ${ }^{13} \mathrm{C}$ and ${ }^{15} \mathrm{~N}$ NMR was previously observed [17]. Also, the $\mathrm{NH} / \mathrm{OH}$ exchange as well as proton exchange is a familiar feature on metal centers [18-20].

The crystal structure of the compounds $\mathbf{2}$ and $\mathbf{4}$ were determined by X-ray analysis. The crystallographic data are presented in Table 1. The ORTEP representations of the two compounds are illustrated in Figures $\mathbf{1}$ and 2. Selected bond lengths and angles are given in Tables 2 and 3 . The crystal analysis revealed that the two compounds crystallized in the monoclinic space group $P 2_{1} / \mathrm{c}$ with a $\mathrm{Z}$ value of 4 . From the structural analysis of compound 2 (Figure 1), it can be noted that the compound is totally unsymmetrical having the point group $C_{s}$. The fragments N1-C19-C18 and N1-C19-C9 are planar which revealed the $s p^{2}$ hybridization of the $\mathrm{N} 1, \mathrm{C} 19$ and $\mathrm{C} 18$ atoms. The bond angles between these atoms lie in the range of $120^{\circ}$ (Table 2). Also, the bond angle C19-N1$\mathrm{H} 1$ is linear $\left(179.9^{\circ}\right)$. Furthermore, the bond length of C19-N1 is $1.212 \AA$, which is shorter than the normal single $\mathrm{C}-\mathrm{N}$ bond (vide infra), and indicated the presence of double bond character [21,22]. The bond angles in the azomethine part (C11-N5-C13) showed the presence of

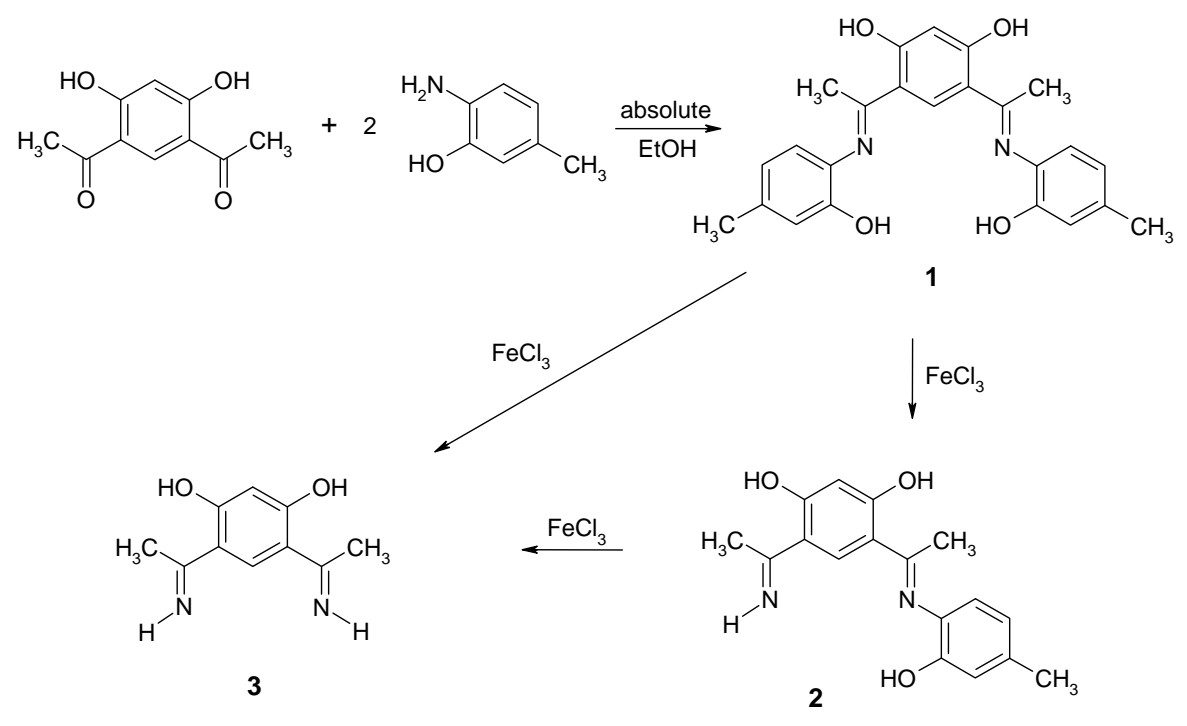

Scheme 1. Synthesis scheme of compounds 2 and 3. 
<smiles>C/C(=N/N)c1cc(/C(C)=N/N)c(O)cc1O</smiles><smiles>CC1=Nc2cc(O)c(/C(C)=N/O)cc21</smiles><smiles></smiles><smiles></smiles><smiles>CN=C(C)C1=CC(=C(C)C)C(N)=CC1O</smiles><smiles></smiles><smiles>CC(=O)c1cc(/C(C)=N/N)c(O)cc1N</smiles>

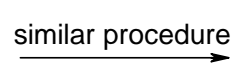<smiles>CC(=O)c1cc(C(C)=O)c(N)cc1N</smiles>

4

Scheme 2. Suggested mechanism for the formation of the two compounds 2 and 4.

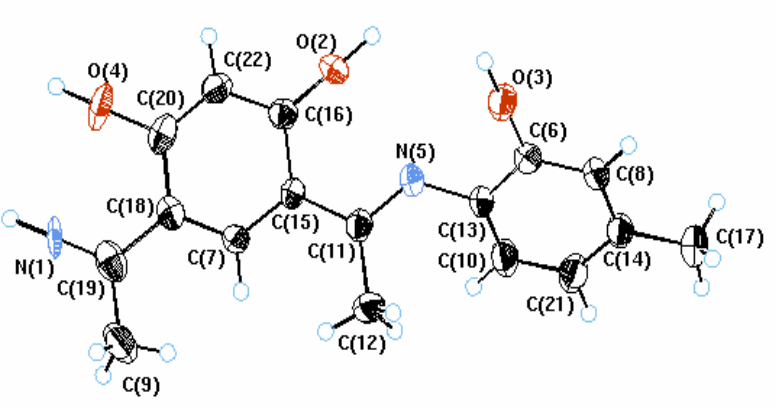

Figure 1. The ORTEP projection of 2.

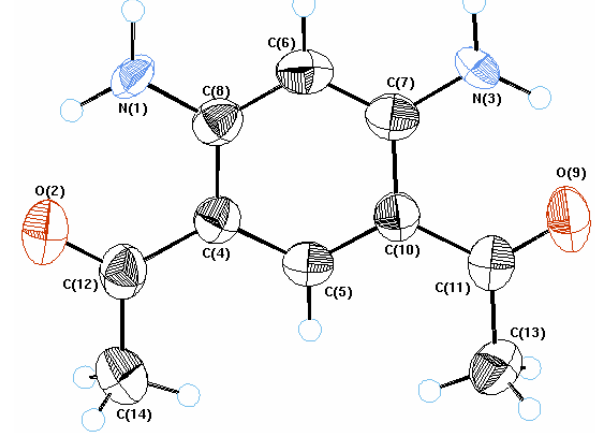

Figure 2. The ORTEP projection of 4. 
Table 2. Selected bond lengths ( $\AA$ ) and bond angles ( $\left(^{\circ}\right)$ for compound 2.

\begin{tabular}{|c|c|c|c|}
\hline \multicolumn{4}{|c|}{ Bond lengths $(\AA)$} \\
\hline N1-C19 & $1.212(5)$ & C7-C18 & $1.382(5)$ \\
\hline $\mathrm{O} 2-\mathrm{C} 16$ & $1.281(4)$ & C8-C14 & $1.370(5)$ \\
\hline O3-C6 & $1.355(4)$ & $\mathrm{C} 11-\mathrm{C} 12$ & $1.514(5)$ \\
\hline $\mathrm{O} 4-\mathrm{C} 20$ & $1.339(5)$ & $\mathrm{C} 11-\mathrm{C} 15$ & $1.438(5)$ \\
\hline N5-C11 & $1.324(5)$ & $\mathrm{C} 14-\mathrm{C} 17$ & $1.505(6)$ \\
\hline N5-C13 & $1.431(5)$ & $\mathrm{C} 14-\mathrm{C} 21$ & $1.410(5)$ \\
\hline $\mathrm{C} 6-\mathrm{C} 8$ & $1.392(5)$ & $\mathrm{C} 15-\mathrm{C} 16$ & $1.455(5)$ \\
\hline C6-C13 & $1.400(5)$ & $\mathrm{C} 16-\mathrm{C} 22$ & $1.415(6)$ \\
\hline C7-C15 & $1.396(5)$ & C18-C19 & $1.469(5)$ \\
\hline $\mathrm{C} 18-\mathrm{C} 20$ & $1.441(6)$ & $\mathrm{C} 20-\mathrm{C} 22$ & $1.353(5)$ \\
\hline C9-C19 & $1.514(7)$ & C9-C19 & $1.514(7)$ \\
\hline $\mathrm{C} 10-\mathrm{C} 13$ & $1.382(5)$ & $\mathrm{C} 10-\mathrm{C} 21$ & $1.382(6)$ \\
\hline N1-H1 & $0.960(3)$ & $\mathrm{O} 2-\mathrm{H} 2$ & $0.960(2)$ \\
\hline $\mathrm{O} 3-\mathrm{H} 3$ & $0.960(3)$ & O4-H4 & $0.960(3)$ \\
\hline \multicolumn{4}{|c|}{ Bond angles $\left({ }^{\circ}\right)$} \\
\hline C11-N5-C13 & $127.2(3)$ & O4-C20-C18 & $119.3(3)$ \\
\hline $\mathrm{O} 3-\mathrm{C} 6-\mathrm{C} 8$ & $123.3(3)$ & C6-C8-C14 & $121.4(3)$ \\
\hline O3-C6-C13 & $117.4(3)$ & $\mathrm{C} 13-\mathrm{C} 10-\mathrm{C} 21$ & 120.7 (3) \\
\hline C8-C6-C13 & $119.3(3)$ & N5-C11-C12 & $120.4(3)$ \\
\hline C15-C7-C18 & $123.4(3)$ & N5-C11-C15 & $118.2(3)$ \\
\hline N1-C19-C9 & $119.9(4)$ & C12-C11-C15 & $121.5(3)$ \\
\hline N1-C19-C18 & $121.3(4)$ & C19-N1-H1 & $179.9(7)$ \\
\hline C9-C19-C18 & $118.8(4)$ & $\mathrm{C} 16-\mathrm{O} 2-\mathrm{H} 2$ & $180.0(2)$ \\
\hline $\mathrm{C} 6-\mathrm{O} 3-\mathrm{H} 3$ & $179.9(9)$ & $\mathrm{O} 4-\mathrm{C} 20-\mathrm{C} 22$ & $119.5(4)$ \\
\hline C20-O4-H4 & $179.6(3)$ & N5-C13-C6 & $117.4(3)$ \\
\hline N5-C13-C10 & $122.7(3)$ & C6-C13-C10 & $119.6(3)$ \\
\hline $\mathrm{C} 8-\mathrm{C} 14-\mathrm{C} 17$ & $121.1(3)$ & C8-C14-C21 & $119.0(4)$ \\
\hline
\end{tabular}

Table 3. Selected bond lengths ( $\AA$ ) and bond angles ( $\left(^{\circ}\right)$ for compound 4.

\begin{tabular}{cccc}
\hline & \multicolumn{2}{c}{ Bond lengths $(\AA)$} & \\
\hline N1-C8 & $1.338(6)$ & $\mathrm{C} 5-\mathrm{C} 10$ & $1.384(7)$ \\
O2-C12 & $1.226(7)$ & $\mathrm{C} 6-\mathrm{C} 7$ & $1.362(8)$ \\
N3-C7 & $1.348(7)$ & $\mathrm{C} 6-\mathrm{C} 8$ & $1.377(8)$ \\
C4-C5 & $1.401(7)$ & $\mathrm{C} 7-\mathrm{C} 10$ & $1.440(8)$ \\
C4-C8 & $1.415(8)$ & O9-C11 & $1.224(7)$ \\
C4-C12 & $1.476(8)$ & $\mathrm{C} 10-\mathrm{C} 11$ & $1.452(7)$ \\
C11-C13 & $1.521(9)$ & $\mathrm{C} 12-\mathrm{C} 14$ & $1.525(9)$ \\
N1-H1A & $0.960(4)$ & N1-H1B & $0.960(4)$ \\
N3-H3A & $0.960(4)$ & N3-H3B & $0.960(4)$ \\
& & & \\
C5-C4-C8 & $117.7(5)$ & N1-C8-C6 & $119.0(5)$ \\
C5-C4-C12 & $122.3(5)$ & $\mathrm{C} 4-\mathrm{C} 8-\mathrm{C} 6$ & $120.9(5)$ \\
C8-C4-C12 & C5-C10-C7 & $116.8(5)$ \\
C4-C5-C10 & C5-C10-C11 & $122.8(5)$ \\
C7-C6-C8 & $119.9(5)$ & $\mathrm{C} 7-\mathrm{C} 10-\mathrm{C} 11$ & $120.4(5)$ \\
N3-C7-C6 & $122.7(5)$ & O9-C11-C10 & $121.2(6)$ \\
N3-C7-C10 & $120.4(5)$ & O9-C11-C13 & $118.7(5)$ \\
C6-C7-C10 & $119.8(5)$ & C10-C11-C13 & $120.1(5)$ \\
N1-C8-C4 & $118.7(5)$ & O2-C12-C4 & $120.4(6)$ \\
O2-C12-C14 & $121.5(5)$ & C4-C12-C14 & $120.1(5)$ \\
C8-N1-H1A & $120.1(5)$ & C8-N1-H1B & $119.9(4)$ \\
H1A-N1-H1B & $119.5(5)$ & C7-N3-H3A & $121.4(4)$ \\
C7-N3-H3B & $120.1(4)$ & H3A-N3-H3B & $120.0(4)$ \\
\hline
\end{tabular}


conjugation between the $\mathrm{C}-\mathrm{N}$ bonds and the two phenyl groups attached to the group (1.431 and $1.324 \AA$ ). The $\mathrm{X}$-ray analysis of compound 2 showed that it contains 3 $\mathrm{OH}$ groups attached to the phenyl rings. Interestingly, the $\mathrm{C}-\mathrm{O}$ bond length of the $\mathrm{OH}$ group attached to the position para to the $\mathrm{C}-\mathrm{N}-\mathrm{H}$ group $\left(\mathrm{C}_{16}-\mathrm{O}_{2}=1.281 \AA\right)$ is shorter than the other $\mathrm{C}-\mathrm{O}$ bonds $\left(\mathrm{C}_{6}-\mathrm{O}_{3}=1.355 \AA\right.$ and $\mathrm{C}_{20}-\mathrm{O}_{4}=1.339 \AA$ ). The content of one unit cell (Figure 3) showed that the dihydroxy phenyl moieties of every two molecules are located in opposite faces and are parallel. This could be due to a charge transfer between every two moieties with $\pi-\pi *$ type of interaction [23].

The X-ray crystal analysis of compound 4, Figure 2, revealed that it has a $C_{2}$ axis of rotation with two planes of symmetry perpendicular to the symmetry axis $\left(C_{2 v}\right.$ symmetry). The bond angles between atoms are consistent with such symmetry (Table 3). However, the O-C-C angles located near the nitrogen atoms are slightly wider than the other angles. The bond length of $\mathrm{C}-\mathrm{N}$ bond is typically single bond $\left(\mathrm{N}_{1}-\mathrm{C}_{8}=1.338 \AA\right.$ and $\mathrm{N}_{3}-\mathrm{C}_{7}=$ $1.348 \AA$ ) [21,22]. On the other hand, the C-O bond lengths are consistent with the presence of double bond character $\left(\mathrm{O}_{2}-\mathrm{C}_{12}=1.226 \AA\right.$ and $\left.\mathrm{O}_{9}-\mathrm{C}_{11}=1.224 \AA\right)$ $[21,22]$. These bond lengths are shorter than the single C-O bonds observed for compound 2 (Scheme 1). The unit cell packing of 4 (Figure 4) exhibited that the

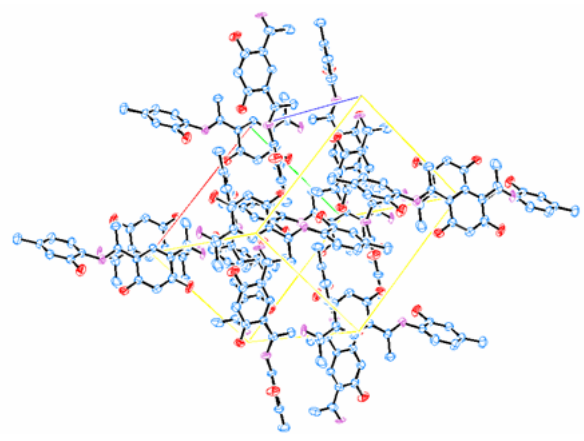

Figure 3. The unit cell packing of 2. Hydrogen atoms are omitted for clearance.

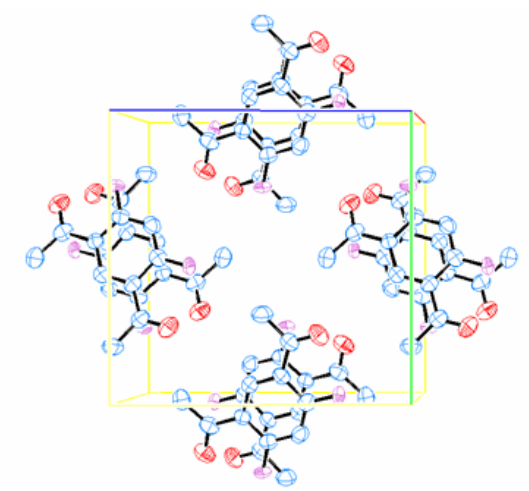

Figure 4. The unit cell packing of 4 . Hydrogen atoms are omitted for clearance. molecules are located in opposite faces and are in parallel stacks. Again, this could be due to a charge transfer between every two molecules with $\pi-\pi^{*}$ type of interaction [23].

\section{Conclusion}

Reactions of 4,6-di[(1E)-N-(2-hydroxy-4-methylphenyl)ethanimidoyl]-benzene-1,3-diol with some metal ions resulted in fragmentation of the compound followed by amido/hydroxyl exchange via unusual catalytic process to yield finally 4,6-diacetyl-1,3-diaminobenzene.

\section{Supplementary Data}

Supplementary crystallographic data (Atomic positional parameters, all bond lengths and angles, anisotropic temperature factors and the calculated and observed structure factors) are available from the CCDC, 12 Union Road, Cambridge CB2 IEZ, UK on request, deposition number: CCDC for: (2) 821862; (4) 821863.

\section{Acknowledgements}

The authors are grateful to the Deanship of Scientific Research, Taibah University, Almadinah Almunawrah, $\mathrm{KSA}$, for the generous financial support of the project no. $431 / 775$.

\section{REFERENCES}

[1] S. J. Archibald, "Coordination Chemistry of Macrocyclic Ligands," Annual Reports Section A (Inorganic Chemistry), Vol. 105, 2009, pp. 297-322. doi:10.1039/b818281g

[2] Z. Chu, W. Huang, L. Wang and S. Gou, "Chiral 27Membered [3 + 3] Schiff-Base Macrocycles and Their Reactivity with First-Row Transition Metal Ions," Polyhedron, Vol. 27, No. 3, 2008, pp. 1079-1092. doi:10.1016/i.poly.2007.12.003

[3] T. Dudev and C. Lim, "Tetrahedral vs Octahedral $\mathrm{Zn}^{2+}$ Complexes with Ligands of Biological Interest: A DFT/ CDM Study," Journal of the American Chemical Society, Vol. 122, No. 45, 2000, pp. 11146-11153. doi:10.1021/ja0010296

[4] T. Dudev and C. Lim, "Modeling $\mathrm{Zn}^{2+}$-Cysteinate Complexes in Proteins," The Journal of Physical Chemistry, Vol. 105, No. 43, 2001, pp. 10709-10714. doi:10.1021/jp012090f

[5] S. S. David and E. Meggers, "Inorganic Chemical Biology: From Small Metal Complexes in Biological Systems to Metallo-Proteins," Current Opinion in Chemical Biology, Vol. 12, 2008, pp. 194-197. doi:10.1016/j.cbpa.2008.03.008

[6] S. J. S. Flora and V. Pachauri, "Chelation in Metal Intoxication," International Journal of Environmental Research and Public Health, Vol. 7, 2010, pp. 2745-2788. doi:10.3390/ijerph7072745 
[7] B. Mabad, P. Cassoux, J. P. Tuchagues and D. N. Hendrickson, "Manganese(II) Complexes of Polydentate Schiff Bases. 1. Synthesis, Characterization, Magnetic Properties, and Molecular Structure," Inorganic Chemistry, Vol. 25, No. 9, 1986, pp. 1420-1431. doi:10.1021/ic00229a025

[8] D. N. Marks, W. Siegl and R. R. Gagne, "Synthesis and Characterization of Mononuclear and Binuclear Ruthenium Complexes of 1,3-Bis(2-pyridylimino)isoindolines," Inorganic Chemistry, Vol. 21, No. 8, 1982, pp. 3140-3147. doi:10.1021/ic00138a044

[9] L. T. Bozic, E. Marotta and P. Traldi, "Efficient SolidState Microwave-Promoted Complexation of a Mixed Dioxa-Diaza Macrocycle with an Alkali Salt. Synthesis of a Sodium Ethyl 4-Benzeneazophosphonate Complex," Polyhedron, Vol. 26, No. 8, 2007, pp. 1663-1668. doi:10.1016/i.poly.2006.12.012

[10] A. Altomare, G. Cascarano, C. Giacovazzo, A. Guagliardi, M. C. Burla, G. Polidori and M. Camalli, "SIR92-A Program for Automatic Solution of Crystal Structures by Direct Methods," Journal of Applied Crystallography, Vol. 27, 1994, p. 435.

[11] S. Mackay, C. J. Gilmore, C. Edwards, N. Stewart and K. Shankland, "Maxus Computer Program for the Solution and Refinement of Crystal Structures," Nonius, MacScience, 1999.

[12] R. M. Silverstein, G. C. Bassler and T. C. Morrill, "Spectrometric Identification of Organic Compounds," 4th Edition, Wiley, New York, 1991.

[13] M. A. Taher, S. E. Jarelnabbi, B. E. Bayoumi, S. M. El-Medani and R. M. Ramadan, "Synthesis and Spectroscopic Studies of Some New Molybdenum, Tungsten and Ruthenium Carbonyl Derivatives of 2-Hydroxymethylpyridine," International Journal of Inorganic Chemistry, Vol. 2010, 2010, Article ID: 296215. doi:10.1155/2010/296215

[14] M. A. Taher, S. E. Jarelnabbi, A. G. M. Al-Sehemi, S. M. El-Medani and R. M. Ramadan, "Synthesis and Spectroscopic Studies of Some New Metal Carbonyl Derivatives of 1-(2-Pyridylazo)-2-naphthol," Journal of Coordination Chemistry, Vol. 62, No. 8, 2009, pp. 1293-1301. doi:10.1080/00958970802541736

[15] O. A. M. Ali, L. H. Abdel-Rahman and R. M. Ramadan, "Ruthenium Carbonyl Derivatives of N-salicylidene-2-hy- droxyaniline Schiff Base," Journal of Coordination Chemistry, Vol. 60, 2007, pp. 2335-2342.

doi:10.1080/00958970701263952

[16] S. M. El-Medani, O. A. M. Ali, H. A. Mohamed and R. M. Ramadan, "Spectroscopic, Thermal and X-Ray Crystal Structure Studies of Some Bis-(pyrazine-2-carboxylato) Nickel(II) Complexes," Journal of Coordination Chemistry, Vol. 58, 2005, pp. 1429-1437. doi:10.1080/00958970500156761

[17] J. Schram, M. Tkadlecová, S. Pataridis, L. Soukupová, V. Blechta, J. Roithová and O. Exner, "Ring-Substituted Benzohydroxamic Acids: ${ }^{1} \mathrm{H},{ }^{13} \mathrm{C}$ and ${ }^{15} \mathrm{~N}$ NMR Spectra and NH-OH Proton Exchange," Magnetic Resonance in Chemistry, Vol. 43, 2005, pp. 535-542. doi: $10.1002 / \mathrm{mrc} .1586$

[18] P. Bindu, J. V. Kingston and M. N. S. Rao, "Dianionic Silicate Derivatives of Transition Metals: Synthesis by a Facile Ion Exchange Route, Characterization and Thermolysis Studies," Polyhedron, Vol. 23, No. 4, 2004, pp. 679-686. doi:10.1016/j.poly.2003.11.003

[19] S. Kannan, A. J. James and P. R. Sharp, "Reaction Chemistry of $\left[\mathrm{Pd}_{2}(\mu-\mathrm{OH})_{2} \mathrm{~L}_{4}\right]^{2+}$ with Aryl Amines.: Structures of $\left[\mathrm{Pd}_{2}(\mu-\mathrm{OH})\{\mu-\mathrm{NH}(p\right.$-tol $\left.)\}\left(\mathrm{PPh}_{3}\right)_{4}\right]\left(\mathrm{BF}_{4}\right)_{2},\left[\mathrm{Pd}\left(\eta^{3}-\mathrm{CH}_{2} \mathrm{C}-\right.\right.$ $\left(\mathrm{NH}(p\right.$-tol $\left.\left.) \mathrm{CH}_{2}\right)\left(\mathrm{PPh}_{3}\right)_{2}\right]\left(\mathrm{BF}_{4}\right)$ and

$\left[\mathrm{Pd}\left(\mathrm{PMe}_{2} \mathrm{Ph}\right)_{2}\left(\mu-\mathrm{PF}_{2} \mathrm{O}_{2}\right)\right]_{2}\left(\mathrm{PF}_{6}\right)_{2}$," Inorganica Chimica Acta, Vol. 345, 2003, pp. 8-14. doi:10.1016/S0020-1693(02)01278-1

[20] F. A. Cotton, G. Wilkinson, C. A. Murillo and M. Bochmann, "Advanced Inorganic Chemistry," 6th Edition, Willey, New York, 1999.

[21] F. H. Allen, O. Kennard, D. G. Watson, L. Brammer and A. G. Orpen, "Tables of Bond Lengths Determined by $X$-Ray and Neutron Diffraction. Part 1. Bond Lengths in Organic Compounds," Journal of the Chemical Society, Perkin Transactions II, Vol. 12, 1987, pp. S1-S19. doi:10.1039/p298700000s 1

[22] J. E. McMurry, "Organic Chemistry," 6th Edition, Brooks/ Cole Pub. Co., Pacific Grove, 2003.

[23] S. M. El-Medani, T. A. Youssef and R. M. Ramadan, "Spectroscopic and X-Ray Crystal Structural Characterization of the Charge Transfer Complexes of 2-Aminobenzimidazole with Some Nitrobenzene Derivatives," Journal of Molecular Structure, Vol. 644, 2003, pp. 7787. doi:10.1016/S0022-2860(02)00474-X 